Methods

- Multi-agency steering group created.

- Systematic review of inequality for homelessness to inform project.

- Interviews with homeless service users and providers.

- Funding obtained.

- Project plan developed:

- Planning: May 2020 - July 2020

- Research: Aug. 2020 - Sept. 2020

- Delivery: Oct. 2020 - July 2021

○ Evaluation: Aug. 2021 - Oct. 2021

- Outcome measures agreed.

- Regular reporting to funders/sponsors against agreed outcome measures.

Results

\begin{tabular}{|c|c|}
\hline Anticipated & Actual \\
\hline Increased referrals & $\begin{array}{l}2015-2020 \text { - six referrals. } \\
\text { May 2020- present - } 17 \text { referrals }\end{array}$ \\
\hline Develop multi-agency links & $\begin{array}{l}\text { Multi-agency steering group } \\
\text { Gold Standards meeting initiated } \\
\text { Relationships developing city-wide including; homeless } \\
\text { shelters, outreach services, ED, liver unit, addiction services, } \\
\text { district nurses. }\end{array}$ \\
\hline $\begin{array}{l}\text { Reduce barriers to } \\
\text { healthcare }\end{array}$ & $\begin{array}{l}\text { Collaborative working, advocacy, service promotion, } \\
\text { education, shared patient records, development of hand- } \\
\text { held records }\end{array}$ \\
\hline $\begin{array}{l}\text { Enable patients to die in } \\
\text { their preferred place }\end{array}$ & $\begin{array}{l}\text { 15/17 patients involved in advance care planning } \\
\text { Use of EPaCCS shared record } \\
\text { Patients supported in: hospice, temporary housing, care } \\
\text { homes/hostel } \\
\text { Developed healthcare/homeless services teaching resources } \\
\text { Integrated Marie Curie Toolkit }\end{array}$ \\
\hline $\begin{array}{l}\text { Improve end-of-life } \\
\text { outcomes }\end{array}$ & $\begin{array}{l}\text { Patients and families reconnected } \\
\text { Hospital avoidance } \\
\text { Pets housed } \\
\text { Patients supported to engage/attend hospital appointments }\end{array}$ \\
\hline
\end{tabular}

Conclusion Increased numbers of homeless patients have been supported by PC services in Leeds. Referrals continue to rise with positive word of mouth. Patients are achieving end-of-life care in their preferred place. Health care professionals and homeless workers have been empowered to manage the complex needs of this group, supporting people to die with dignity and choice.

\section{P-8 PATIENTS WITH LEARNING DISABILITIES: IDENTIFYING BARRIERS}

Syed Qamar Abbas, Jonathan Riordan, Enam Hosein Khan. St Clare Hospice, Harlow, UK

\subsection{6/spcare-2021-Hospice.29}

Introduction Learning disabilities (LD) affect about 1.5 million people in the UK and are common, lifelong conditions which are neither illness nor disease. 1200 people with LD die in hospital each and every year and one in three health professionals think they receive worse quality healthcare than those without learning disability. At St Clare Hospice, we developed a special interest group and explored barriers and possible ways to deal with those barriers.

Methods A group was developed with membership from hospice, primary care, hospital, social services and other stakeholders. A survey was carried out with hospice staff about their confidence in supporting patients with LD. Following that a group meeting was held to discuss barriers and methods to deal with that.

Analysis and Results Ten hospice and LD staff returned the survey. Twelve professionals with medical, specialist, nursing and managerial backgrounds attended a focus group discussion. The following themes for barriers were recognised:

- Lack of knowledge among staff on needs of patients with LD.

- Communication difficulties.

- Poor co-ordination between services.

- Lack of understanding by families about services.

- Often complex family and social circumstances.

- Referral criteria and the lack of understanding of the differences between 'learning disability' and 'learning difficulties'.

- Misunderstanding about the services the hospice offers and assumptions that people are admitted to die.

- Delayed referrals to palliative care by primary and secondary care.

- Lack of knowledge about family support work.

- Fear of foreshortening life by referrals.

- Lack of pathway of care for patients with LD.

- Lack of advance care planning.

The following themes were identified for training:

- Data on patients with LD.

- Service users' experiences.

- Symptom management.

- Issues around death and dying.

- Communication sessions.

- Bereavement sessions.

- Advance care planning.

- Support for staff looking after patients with LD.

Conclusion There is a need to develop collaborative initiatives for palliative care for patients with LD, working across hospice, hospital, primary care, social services and care homes.

\section{P-9 SURVEYING THE LANDSCAPE: LIVING, DYING AND REMEMBERING WITH A LEARNING DISABILITY}

Ian Leech, Nikki Archer. St Giles Hospice, Lichfield, UK

10.1136/spcare-2021-Hospice.30

Background An aim of the funded learning disability project was to learn more about the knowledge base of the hospice staff around learning disabilities at end-of-life/bereavement; whilst also exploring how hospice care was perceived by those working in the learning disability community. National reports and research (LeDeR programme, 2018; Hunt et al., 2019; Heslop, Blair, Fleming et al., 2013; Oliver, 2017) have highlighted the need to improve end-of-life care and bereavement support for people with learning disabilities, so we explored our learning disability landscape through a survey. 